The apparent diversity in how cortical territories that process similar forms of information are charted during development encourages further investigation - both into how this process occurs, and why such territories need to be parcelled out in the first place.

Rachel O. L. Wong is in the Department of Anatomy and Neurobiology, Washington University School

of Medicine, 660 South Euclid, St Louis,

Missouri 63110, USA.
1. Weliky, M. \& Katz, L. C. Nature 386, 680-685 (1997)

2. Nicholls, J. G., Martin, A. R. \& Wallace, B. G. From Neuron to Brain (Sinauer, Sunderland, MA, 1984).

3. Hubel, D. H. \& Wiesel, T. N. J. Physiol. Lond. 160, 106-154 (1962).

4. Chapman, B. \& Stryker, M. P. J. Neurosci. 13, 5251-5262 (1993).

5. Chapman, B., Stryker, M. P. \& Bonhoeffer, T. J. Neurosci. 15, 6443-6453 (1996)

6. Kim, D.-S. \& Bonhoeffer, T. Nature 370, 370-372 (1994)

7. Gödeke, I. \& Bonhoeffer, T. Nature 379, 251-254 (1996).

8. Miller, K. D. J. Neurosci. 14, 409-441 (1994).

9. Goodman, C. S. \& Shatz, C. J. Cell/Neuron 72/10, 77-98 (1993).

10. Stryker, M. P. \& Strickland, S. L. Invest. Ophthalmol. Vis. Sci. (Suppl.) 25, 278 (1984)

\title{
Ecology
}

\section{Bog standards in Minnesota}

\author{
Peter D. Moore
}

$\mathrm{T}$ he idea of a raised bog may seem something of a contradiction in terms most wetland habitats are low-lying and receive drainage water from a surrounding catchment. But the raised, or domed, bog is a very widespread, if declining, type of mire in the temperate zone of the Northern Hemisphere, especially in the more oceanic regions (Fig. 1). The debate about how a wetland can maintain its surface several metres above the groundwater table and yet avoid desiccation has simmered for a century. Do these domed masses of peat pull up water from below by capillarity? Or do they impede the downward movement of rain water as a consequence of the impermeable nature of compacted peat? Or are they dependent on hydrostatic pressure from below, as is suggested by research by Glaser, Siegel, Romanowicz and Shen reported in the current issue of Journal of Ecology'?

Raised bogs are dome-shaped structures, often several kilometres in diameter and achieving peat depths in excess of $10 \mathrm{~m}$. They develop in a variety of ways, often as a result of the infilling of lake sites by plant successions that run from swamp forests to communities dominated by bog moss (Sphag-

num spp.), which is usually the main peatforming vegetation of the rising peat dome. Such bogs may also arise within estuarine sites or over alluvial swamps and fens, as in the fenlands of eastern Britain.

The exploitation of the peat deposits as a source of horticultural soil conditioners, or of energy, has led to the loss of many raised bogs, especially in highly populated regions of the temperate zone such as Britain and Germany. Some of the areas where peat has been removed most effectively are also zones of lower precipitation, as in the case of southeast England, so most studies of raised bogs have been conducted in the high-precipitation regions where these mires are most frequent. The conditions necessary for the formation of raised bogs in relatively drier areas are consequently poorly understood.

The accumulation of large volumes of peat during the formation of a raised bog clearly demands waterlogged conditions in which microbial activity is impeded and decomposition fails to account for the totality of litter formation. So the problem arises as to how a raised bog can maintain surface wetness. The remarkable water-holding capacity of Sphagnum mosses (up to 20 times

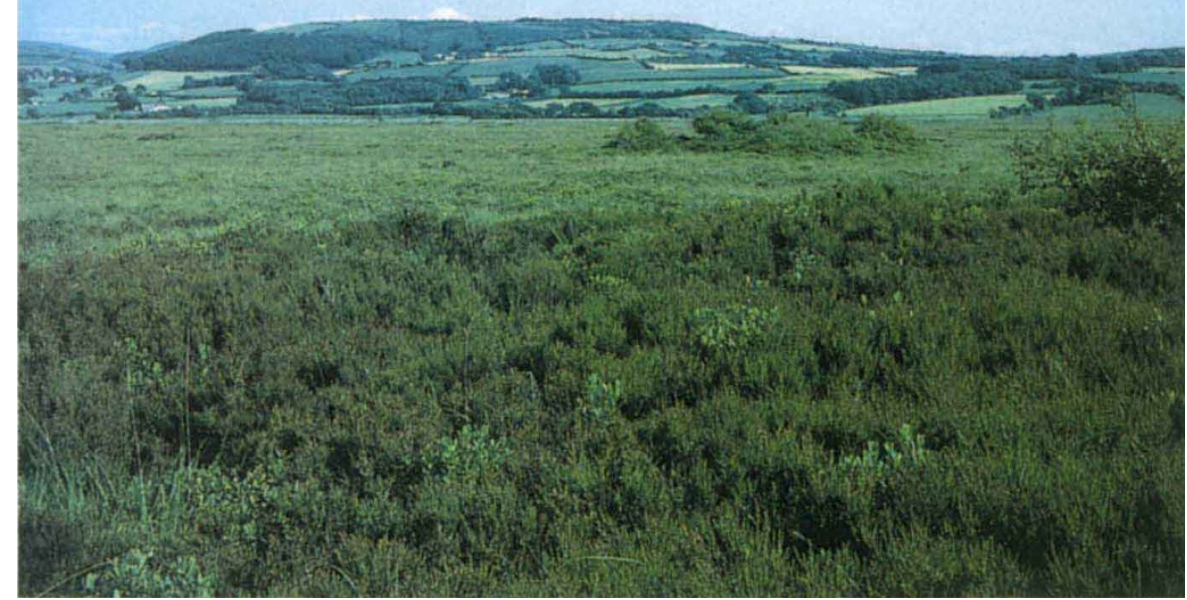

Figure 1 High mire - a raised bog, Cors Fochno, west Wales.

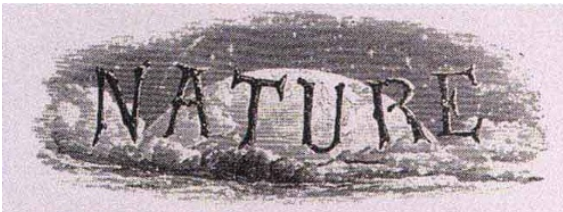

100 YEARS AGO

When mine host in the ideal country inn, which all of us seek but none of us find, brings up a bottle of crusted wine covered with cobwebs and dust, this outward and visible sign is taken as convincing evidence of age. We grieve to have to record that the trust may now be misplaced. A Bulletin (No. 7) of the Division of Entomology of the U.S. Department of Agriculture says that in France and Pennsylvania an industry has recently sprung up, which consists of the farming of spiders for the purpose of stocking wine cellars, and thus securing almost immediate coating of cobwebs to new wine-bottles, giving them the appearance of great age. ... This application of entomology to industry is one which will not be highly commended.

From Nature 15 April 1897.

\section{YEARS AGO}

An Ecstasy. By Marie Carmichael Stopes Pp.iv + 19. (London: Alexander Moring, Ltd., 1946.) 5 s.

Of the lyrical quality of this poem, as indeed of all Dr. Stopes' verse, there is no question:

"Brown rocks have sucked in all the sun's warm rays

To over brimming, till they fill the air

To fine enraptured whirlpuffs gliding where

They quiver up the bank of sheltered bays",

... But the author's enraptured journey tends to veil her powers of discretion. Imagination is not necessarily art.

"Soon my salt tanged palms

Vie with intoxicating scent brewed balms,

To yield sweet odours to the sun drenched sky.

Short golden hairs, minutest flagstaffs rear Each on its tiny mound, but soon they cling

Content to nestle close like folded wing." Avoiding this misguided sensuousness, Dr. Stopes would be a poet of quality, and a stronghold for readers who deplore the absence of buoyancy in modern poetry. Margaret Howard.

From Nature 19 April 1947.

Many more extracts like these can be found in A Bedside Nature: Genius and Eccentricity in Science, 1869-1953, a 266-page book edited by Walter Gratzer. Contact David Plant (e-mail: subscriptions@nature.com). 